Title:

\title{
Redox stability of metal-supported fuel cells with nickel/gadolinium-doped ceria anode
}

\author{
Authors: \\ Florian Thaler ${ }^{1,2}$, David Udomsilp ${ }^{1,2}$, Wolfgang Schafbauer ${ }^{3}$, Cornelia Bischof ${ }^{1,3}$, Yosuke Fukuyama ${ }^{4}$, \\ Yohei Miura4, Mari Kawabuchi ${ }^{4}$, Shunsuke Taniguchi ${ }^{5}$, Satoshi Takemiya ${ }^{5}$, Andreas Nenning ${ }^{1,6}$, \\ Alexander Karl Opitz ${ }^{1,6}$, Martin Bram ${ }^{1,2}$ \\ ${ }^{1}$ Christian Doppler Laboratory for Interfaces in Metal-supported Electrochemical Energy Converters \\ ${ }^{2}$ Institute of Energy and Climate Research - Materials Synthesis and Processing (IEK-1), Forschungszentrum Jülich GmbH, Germany \\ ${ }^{3}$ Plansee SE, Austria \\ ${ }^{4}$ Nissan Motor Co. Ltd. EV System Laboratory, Japan \\ ${ }^{5}$ Next-Generation Fuel Cell Research Center, Kyushu University, Japan \\ ${ }^{6}$ Institute of Chemical Technologies and Analytics - Research Group for Electrochemical Energy Conversion, TU Wien, Austria
}

\begin{abstract}
:
Metal-supported fuel cells (MSCs) are promising candidates for not only stationary but also mobile applications. Their appeal is in their potential to withstand reoxidation of the anode, which might occur by an interruption of the fuel supply or an emergency shutdown of the fuel cell system. A novel nickel/gadolinium-doped ceria anode (Ni/GDC) was recently introduced in a MSC concept of Plansee, almost doubling power density compared to cells with a nickel/yttria-doped zirconia (Ni/YSZ) anode. In this study, both cell concepts are compared concerning their ability to tolerate harsh redox cycles. Therefore, controlled redox cycles of the anodes were conducted at different temperatures. The response of the cell's power output to the redox cycling experiments was continuously recorded. In the case of MSCs with a Ni/YSZ anode, strong degradation occurs after redox cycling. In contrast, cells with a Ni/GDC anode exhibit significantly improved redox tolerance and cell performance improves with the number of redox cycles. For understanding this behavior, microstructural investigations of the $\mathrm{Ni} / \mathrm{GDC}$ anode and the adjacent electrolyte were performed by FIB-SEM. The long-term redox behavior of MSCs with a Ni/GDC anode was also investigated by conducting more comprehensive redox cycles at $400^{\circ} \mathrm{C}, 500^{\circ} \mathrm{C}$, and $600{ }^{\circ} \mathrm{C}$.
\end{abstract}

\section{Keywords:}

Metal-supported solid oxide fuel cell (MSC); Ni/GDC anode; Ni/YSZ anode; redox cycling; electrochemical testing; FIB-SEM 3D microstructure reconstruction

\section{Introduction}

In the past few decades, metal-supported solid oxide fuel cells (MSCs) attracted attention for nonstationary applications such as auxiliary power units (APUs) in heavy-duty trucks or range extenders in battery electric vehicles (RE BEVs). The advantages of MSCs compared to established full-ceramic solid oxide fuel cells (anode-supported fuel cells, ASCs or electrolyte-supported fuel cells, ESCs) include better thermal cyclability and increased mechanical stability, a good weldability to the metallic 
interconnects within an SOFC stack, and significant potential for lowering manufacturing costs due to the less-expensive metal support.

A variety of different MSC concepts have been established in the past 20 years [1,2]. The development of these kinds of fuel cells has been driven forward by the Lawrence Berkeley National Laboratory (LBNL) and its spin-off company Point Source Power (PSP) [3, 4]; Ceres Power, a spin-off of Imperial College London [5, 6]; Topse Fuel Cell A/S - in cooperation with the Technical University of Denmark (DTU) and Ris $\varnothing$ National Laboratory [7-9]; the German Aerospace Center (DLR) [10]; Austrian company Plansee SE - in close collaboration with Forschungszentrum Jülich $\mathrm{GmbH}$ [11-13]; and other groups at the University of Toronto in Canada [14] as well as universities in the United States, Europe, and Asia. A general issue of SOFCs employing nickel-based anodes is the risk of $\mathrm{Ni}$ oxidation. This oxidation of the anode can occur in the event of i.) an abrupt interruption to the fuel supply; ii.) an emergency shutdown of the SOFC system; iii.) intentionally upon a system shutdown iv.) very high fuel utilization; or v.) a gas leakage from the cathode side. System solutions to prevent the substrate and anode from oxidation, as an automatically maintenance of fuel gas or inert gas supply until the system temperature falls below a critical value, are expensive and not easy to implement technically. Therefore technological solutions to make the anodes more redox tolerant themselves have to be developed. $\mathrm{Ni} / \mathrm{GDC}$ anodes for example are promising candidates since they are suspect to be more redox tolerant than Ni/YSZ anodes, as shown by Iwanschitz et al. [15].

The redox behavior of $\mathrm{Ni} / \mathrm{YSZ}$ and $\mathrm{Ni} / \mathrm{GDC}$ anodes have been the subject of numerous studies in the literature [15-38]. Accordingly, the oxidation and reduction of nickel ( $\mathrm{Ni}$ ) is coupled with a large volume change. During oxidation, volume expansion of up to $71 \%$ of the Ni phase is reported [21] which is in good accordance with the theoretical volume increase of $69,9 \%$ based on the molar volumes of $\mathrm{Ni}$ and nickel oxide ( $\mathrm{NiO}$ ) [23]. As a consequence, irreversible expansion strain occurs in the anode microstructure and internal stresses arise in the anode and the electrolyte. If a critical stress level is exceeded, this results in the cracking or delamination of the electrolyte, which causes a catastrophic failure of the SOFC in most cases [19-23]. This effect is usually accompanied by a breakdown of the ceramic YSZ backbone in cermet anodes [15]. The oxidation of $\mathrm{Ni}$ is a diffusion-controlled process, which results in internal porosity as a side effect [24]. Waldbillig et al. report evidently lower oxidation rates of $\mathrm{Ni}$ if the temperature stays below $700{ }^{\circ} \mathrm{C}$ [25]. However, the reduction of $\mathrm{NiO}$ leads to an up to $42 \%$ volume decrease [26-28]. Under anode conditions, reduction can take place at temperatures above $200^{\circ} \mathrm{C}$ and becomes more pronounced at higher temperatures. As a first step of reduction, $\mathrm{Ni}$ nanoparticles are formed on the NiO surface, leading to a roughening of the surface [29]. The high specific surface area of these nanoparticles leads to a temporary decrease of polarization resistance immediately after a redox cycle [30]. If the cell is subsequently operated under steady-state conditions, $\mathrm{Ni}$ coarsening occurs, which again increases polarization resistance. $\mathrm{Ni}$ agglomeration becomes strongly pronounced at temperatures higher than $600{ }^{\circ} \mathrm{C}[15,30,31]$.

Although the ceramic backbone does not undergo microstructural changes as strong as the Ni phase, it still has a significant influence on the redox behavior of the anode. In the case of $\mathrm{Ni} / \mathrm{YSZ}$ anodes, YSZ is a pure ionic conductor, which mainly contributes to the electrochemical reactions at the triple phase boundaries (TPBs). Redox cycling of the Ni/YSZ anodes is coupled with a steady increase of polarization resistance, while ohmic resistance remains almost constant $[15,30,32]$. It was shown in the literature that in Ni/YSZ anodes, the length of the TPB correlates with anode performance. However, the degradation mechanism is clearly dependent on the initial microstructure [33]. The increase of polarization resistance is explained by a decrease of the active TPB length due to the drastic change of the Ni microstructure, which becomes aggravated with an increasing number of redox cycles $[29,30$, 34]. The refinement of the Ni phase and the formation of elongated grains immediately after a redox 
cycle are reported. Ni grains become more rounded and coarsened if steady-state operation follows the redox cycle. These effects lead to increased tortuosity of the Ni and YSZ, while the tortuosity of the pores decreases.

The redox behavior of Ni/GDC anodes has been less reported in the literature so far $[15,35,36]$. GDC is an attractive material for the ceramic backbone of SOFCs, since it contributes to the electrochemical performance of the anode. At the surface of GDC grains, the oxidation of hydrogen is most likely triggered by its mixed ionic and electronic conductivity (MIEC) under reducing conditions, clearly increasing the electrochemically active surface area [39]. A clear increase of electrochemical performance results from the Ni/YSZ anodes being replaced by Ni/GDC anodes [13, 40]. Furthermore, GDC significantly improves the tolerance against sulfur and carbon deposition if the cell is operated with $\mathrm{H}_{2} \mathrm{~S}$ containing fuels or hydrocarbons, respectively [35, 41]. If applying GDC as a ceramic backbone, certain properties of the ceria phase must be considered. Since $\mathrm{CeO}_{2}$ can be reduced relatively easy, a valence change from $\mathrm{Ce}^{4+}$ to $\mathrm{Ce}^{3+}$ occurs for some of the cerium cations in hydrogen containing atmospheres, which is also responsible for the above mentioned mixed conductivity [42, 43]. In addition, the ionic radius of $\mathrm{Ce}^{3+}$ is significantly larger than that of $\mathrm{Ce}^{4+}$ and the material is therefore prone to chemical expansion, which potentially occurs if sintering is performed under reducing conditions or during operation under anode conditions [44]. In terms of the redox tolerance of GDC containing $\mathrm{Ni}$ anodes, both effects might be helpful due to the possible gettering oxygen during oxidation and due to partial compensation of the Ni volume decrease during reduction. Nevertheless, chemical expansion itself may be fundamentally critical, since it is often accompanied by crack formation [43, 44]. Another interesting aspect of sintering Ni/GDC composites is the enhanced sintering activity of $\mathrm{Ni}$ when it comes into contact with a GDC surface, indicating a strong surface interaction [45]. This effect has a clear influence on the processing of Ni/GDC anodes and accelerates $\mathrm{Ni}$ coarsening during sintering, especially at temperatures above $1000^{\circ} \mathrm{C}$ [13]. However, in the case of redox cycling of the Ni/GDC anodes, the Ni surface becomes increasingly covered with GDC in line with the increasing number of redox cycles [35]. Under certain conditions, this effect might lead to improved electrochemical performance due to an improvement of the GDC-Ni contact area and an increase of the active length of the TPBs. However, a decrease of pore volume was found to be one of the reasons for cell degradation.

In the present study, two different types of metal-supported fuel cells - one with a Ni/YSZ and the other with a Ni/GDC functional anode layer - were manufactured at Plansee SE and tested in terms of their redox tolerance in lab-scale experiments at Kyushu University and Nissan. The base cell concept has a Ni/YSZ anode. Recently, Ni/YSZ was replaced by Ni/GDC in an attempt to improve electrochemical performance $[13,40]$. In this cell concept, applying the electrolyte by magnetron sputtering at moderate temperatures [12] eases the implementation of $\mathrm{Ni} / \mathrm{GDC}$. In ASC or ESC concepts, the chemical reaction between the YSZ electrolyte and GDC in the anode takes place at the usual sintering temperatures for those cells, which is not critical for the Plansee cell manufacturing concept. MSCs are ideally suited for mobile applications, where high redox tolerance is one of the key issues for long-term stability. In the literature, it is suggested that cells with different anode materials behave quite differently if exposed to redox cycles. Redox cycling experiments were therefore conducted under realistic cell test conditions in order to provide a direct comparison between the two anode concepts in the current study. The temperature of the redox cycles was varied between $300{ }^{\circ} \mathrm{C}$ and $700{ }^{\circ} \mathrm{C}$ to determine the maximum tolerable redox temperature and to observe the temperature-dependent microstructural changes. However, it was expected that the cells with the new Ni/GDC anode are much more resistant than cells with the Ni/YSZ anode. Nevertheless, if the number of redox cycles would be 
increased and temperatures exceed $500{ }^{\circ} \mathrm{C}$ the redox stability of the cells is most likely critical, even in the case of $\mathrm{Ni} / \mathrm{GDC}$ anodes.

\section{Experimental}

\subsection{Manufacturing of the Plansee MSC}

The Plansee cell concept used in this study (Figure 1) consisted of a $300-\mu \mathrm{m}$-thick porous metal support (Cr26-Fe, intermediate temperature metal, ITM), a $40 \mu \mathrm{m}$ multilayer anode, a 4- $\mu \mathrm{m}$-thick electrolyte (8YSZ), and a $40 \mu \mathrm{m}$ LSCF cathode as a top layer. To prevent the interdiffusion of certain elements, the metal substrate and the electrolyte were coated with a $500 \mathrm{~nm}$ magnetron-sputtered GDC diffusion barrier layer (DBL). A detailed description of the manufacturing of the cell can be found in Ref. [12]. Plansee SE produced rectangular cells with dimensions of $160 \times 99 \mathrm{~mm}$ - including the metal substrate (1), the graded anode (2), the electrolyte (3), and the two DBLs - from which round button cells with a diameter of $29.5 \mathrm{~mm}$ were cut by laser. A round cathode layer (4) with a diameter of $9 \mathrm{~mm}$ was subsequently screen-printed on top of DBL 2. In order to protect the metallic support from oxidation, the cathode was not sintered but in situ activated at $850{ }^{\circ} \mathrm{C}$ in air during heat-up and sealing procedure in the test rig. The anode side was flushed with an inert-gas/hydrogen mixture in the meanwhile. The particle sizes of the anode materials are diverse, resulting in a coarse-structured Ni/8YSZ base layer (2a) in direct contact with the metal substrate, a finer structured Ni/8YSZ interlayer (2b), and a very fine anode layer (2c) consisting of either $\mathrm{Ni} / \mathrm{YSZ}$ or Ni/GDC, respectively.

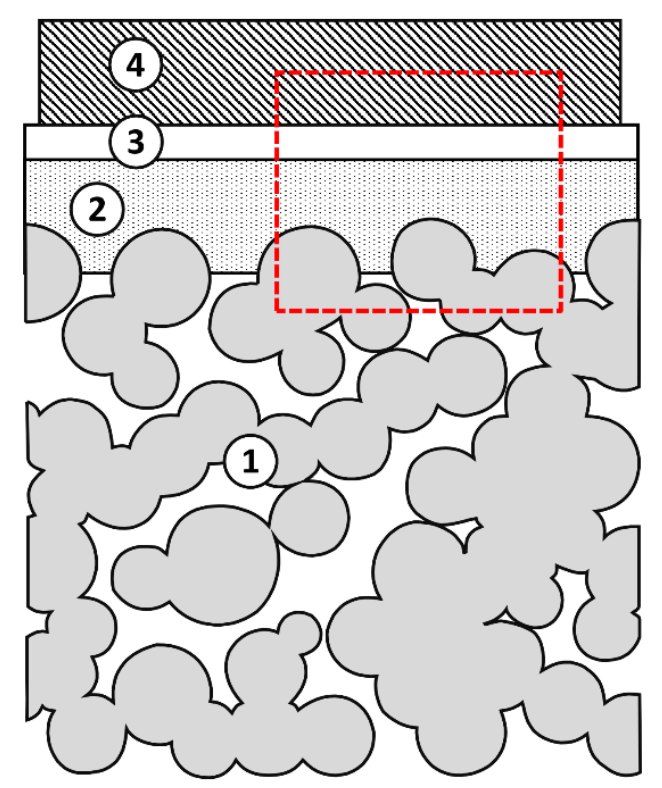

Figure 1: Plansee MSC design

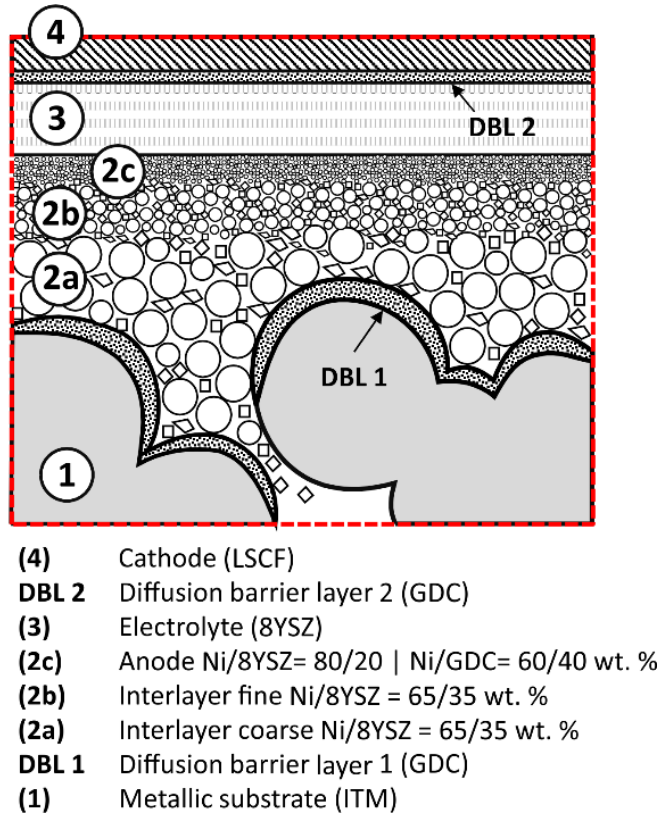

(1) Metallic substrate (ITM)

\subsection{Redox cycling tests}

Redox cycling experiments and microstructural analysis (FIB-SEM, FE-SEM) were performed at Kyushu University and Nissan. All tests were performed on button cells of $\varnothing 29.5 \mathrm{~mm}$ (substrate, anode, and electrolyte) with an active cathode area of $0.64 \mathrm{~cm}^{2}(\varnothing 9 \mathrm{~mm})$, which were laser-cut from larger cells, as described in section 1.1. In this button cell tests, electrical contacting of the electrodes was ensured by platinum mesh current collectors pressed toward the cell by a porous alumina die at each side. The meshes were connected to the circuit analyzer and the impedance spectrometer by platinum wires. Test stations consisted of separate mass flow controllers for air and fuel gas supply, a furnace to heat the cells to operating temperature, and devices for checking electrochemical performance. For the 
anode gas supply, either $\mathrm{H}_{2} / \mathrm{N}_{2}$ or $\mathrm{N}_{2}$ /air mixtures could be selected. Furthermore, the anode gas could be humidified using a water bubbler.

Redox cycling experiments were performed according to one of the both test procedures as a) Shortterm redox cycling and b) Long-term redox cycling on the test cells after an initial performance check including current-voltage curves (I-V) and electrochemical impedance spectroscopy (EIS). According to the short-term cycling test (a), initial cell performance at the beginning of lifetime (BOL) was measured under OCV conditions with air on the cathode side and $\mathrm{H}_{2}$ on the anode side. Afterwards, the cell was cooled to the given anode redox temperature, which was varied between $300{ }^{\circ} \mathrm{C}$ and $700{ }^{\circ} \mathrm{C}$. The $\mathrm{H}_{2}$ supply was then stopped and the anode was purged with $\mathrm{N}_{2}$ before switching to air supply on the anode side for controlled reoxidation. This was followed by another purging step with $\mathrm{N}_{2}$ and subsequent reduction in $\mathrm{H}_{2}$. Each sequence was conducted for $10 \mathrm{~min}$. This redox procedure was repeated 7 times for each temperature, followed by another performance check (I-V + EIS) at $750{ }^{\circ} \mathrm{C}$. A schematic diagram of this cycling experiment at a redox temperature of $300{ }^{\circ} \mathrm{C}$ is shown in Figure 2a. This test procedure was used to directly compare the redox behavior of the two different anode materials $\mathrm{Ni} / 8 \mathrm{YSZ}$ and $\mathrm{Ni} / \mathrm{GDC}$. Following the above-described procedure, the button cells were first reoxidized at $300{ }^{\circ} \mathrm{C}$ for 7 cycles, followed by a performance check at $750^{\circ} \mathrm{C}$ and another 7 cycles at $400{ }^{\circ} \mathrm{C}, 500{ }^{\circ} \mathrm{C}, 600^{\circ} \mathrm{C}$, and $700{ }^{\circ} \mathrm{C}$, respectively. I-V curves and EIS measurements were performed at $750{ }^{\circ} \mathrm{C}$ after every set of redox cycles.

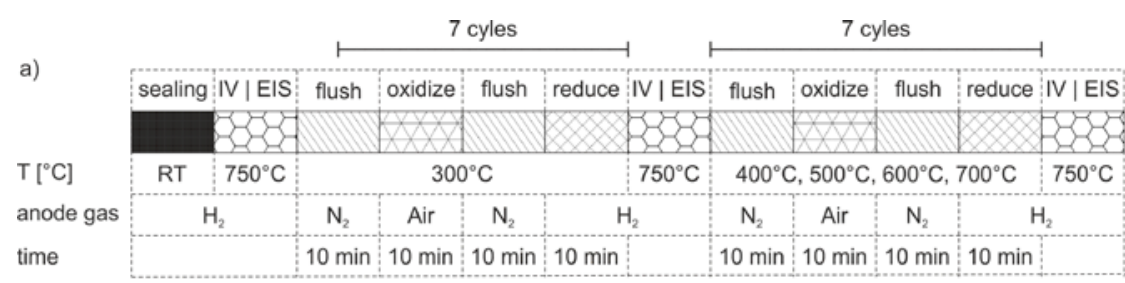

Short-term cycling test

\begin{tabular}{|c|c|c|c|c|c|c|}
\hline \multirow{2}{*}{ b) } & \multicolumn{6}{|c|}{ multiple cyles $1-50$} \\
\hline & sealing IV | EIS & flush & oxidize & flush & reduce & IVIEIS \\
\hline $\mathrm{T}\left[{ }^{\circ} \mathrm{C}\right]$ & $850^{\circ} \mathrm{C}$ & & & $600^{\circ} \mathrm{C}$ & & \\
\hline anode gas & $\mathrm{H}_{2}$ & $\mathrm{~N}_{2}$ & Air & $\mathrm{N}_{2}$ & $\mathrm{H}_{2}$ & \\
\hline time & & $10 \mathrm{~min}$ & $120 \mathrm{~min}$ & $10 \mathrm{~min}$ & $120 \mathrm{~min}$ & \\
\hline
\end{tabular}

Long-term cycling test

Figure 2: Schematic diagram of a) Short-term test sequence and b) Long-term test sequence for the redox cycling experiments.

Test sequence (b) was used to confirm the good redox tolerance of $\mathrm{Ni} / \mathrm{GDC}$ as well as its long-term durability. Therefore, multiple reoxidation cycles were conducted at $600^{\circ} \mathrm{C}$ using the long-term cycling test setup, as illustrated in Figure $2 \mathrm{~b}$. After an initial performance check (I-V + EIS) at $600{ }^{\circ} \mathrm{C}$, the $\mathrm{H}_{2}$ supply was stopped and the anode was purged with $\mathrm{N}_{2}$ for $10 \mathrm{~min}$. For reoxidation of the anode, air was supplied for a period of $120 \mathrm{~min}$, followed by another $10 \mathrm{~min} \mathrm{~N}_{2}$ purge sequence before $\mathrm{H}_{2}$ was then switched on for $120 \mathrm{~min}$ and the electrochemical performance was again checked after the redox cycle at $600{ }^{\circ} \mathrm{C}$. This procedure was repeated for up to 50 redox cycles using button cells with a Ni/GDC anode. This kind of redox cycling test was repeated in a similar way, lowering the reoxidation temperature to $500{ }^{\circ} \mathrm{C}$ and $400{ }^{\circ} \mathrm{C}$. In both cases, fresh button cells were used for the test.

\subsection{D microstructural investigation by FIB-SEM}

The FEl dual-beam system Helios NanoLab600i ${ }^{\circledR}$ at Kyushu University was used to acquire structural information concerning the samples. The system comprises a focused ion beam (FIB) combined with a scanning electron microscope (SEM) to provide detailed insights into the spatial texture of the porous 
anode structure. The FIB unit periodically detaches thin lamellae from the sample surface, which are then recorded layer by layer with the SEM. As a result, the individual microstructures of each lamella can be combined into a three-dimensional image of the probed sample volume. Through digital image processing, each phase can be separated on the basis of different grey values in the SEM images. Volume fractions and the positions of the ceramic and nickel particles as well as the pores can therefore be reconstructed. Furthermore, the tortuosity of the particles and pores, the distribution and density of triple phase boundaries (TPBs), and the interface area of each phase can be calculated from this data. The method of FIB-SEM analysis with 3D microstructure reconstruction is widely used in the literature to investigate SOFC anodes [28-30].

\section{Results and discussion}

Redox cycling experiments on MSC button cells with an LSCF cathode area of $0.64 \mathrm{~cm}^{2}$ were performed for two different anode materials at different temperatures. In the first section, the electrochemical performance of MSCs with an established Ni/YSZ anode in comparison to a novel Ni/GDC anode were investigated in terms of their redox tolerance during short-term cycles (see Figure $2 \mathrm{a}$ ) in a temperature range of $300-700{ }^{\circ} \mathrm{C}$. In addition, the microstructure alteration was also evaluated by SEM and using a 3D microstructure reconstruction technique. Long-term redox cycling tests (according to Figure 2b) on cells with a $\mathrm{Ni} / \mathrm{GDC}$ anode were subsequently conducted to demonstrate the stability of the anodes at temperatures of $600{ }^{\circ} \mathrm{C}, 500^{\circ} \mathrm{C}$, and $400^{\circ} \mathrm{C}$, respectively.

\subsection{Electrochemical performance check before and after short-term redox cycling}

At the beginning of lifetime (BOL) and after 7 redox cycles for each specific temperature $\left(300^{\circ} \mathrm{C}\right.$, $400{ }^{\circ} \mathrm{C}, 500^{\circ} \mathrm{C}, 600^{\circ} \mathrm{C}$, and $700^{\circ} \mathrm{C}$ ), the electrochemical performance of the cells was measured by recording I-V curves and EIS measurements at $750^{\circ} \mathrm{C}$. The results indicate a drastic decline in current density after redox cycling of the $\mathrm{Ni} / \mathrm{YSZ}$ anode at $600^{\circ} \mathrm{C}$ and above (Figure 3a). However, reoxidation in the temperature range of $300{ }^{\circ} \mathrm{C}$ to $500{ }^{\circ} \mathrm{C}$ did not lead to any cell degradation, in comparison to the reference measurement before the redox cycling. $\mathrm{OCV}$ remained constant in the range of $1.03 \mathrm{~V}$ before and after redox cycling at $300-700^{\circ} \mathrm{C}$. The cell with a Ni/GDC anode clearly showed improved redox tolerance, demonstrating that there was no drop in cell performance after redox cycling in the full temperature range from $300{ }^{\circ} \mathrm{C}$ to $700{ }^{\circ} \mathrm{C}$ (Figure 3b). Rather, even a slight performance increase can be seen from the I-V curves in Figure $3 \mathrm{~b}$, which is an indication for microstructural changes in the anode. OCV was not affected by the redox cycling and remained at $1.07 \mathrm{~V}$, same as at beginning of lifetime.

In the case of the $\mathrm{Ni} / \mathrm{YSZ}$ anode, the ohmic resistance also increased with the redox cycling temperature. Especially after cycling at $600{ }^{\circ} \mathrm{C}$ and $700{ }^{\circ} \mathrm{C}$, resistance increased from $0.12 \Omega \mathrm{cm}^{2}$ to $0.3 \Omega \mathrm{cm}^{2}$ (see impedance spectra in Figure 3c). Polarization resistance decreased with higher redox temperature with a low frequency intercept of $0.8 \Omega \mathrm{cm}^{2}$ at BOL, $0.9 \Omega \mathrm{cm}^{2}$ after $300^{\circ} \mathrm{C}, 0.85 \Omega \mathrm{cm}^{2}$ after $400{ }^{\circ} \mathrm{C}$ and $0.5 \Omega \mathrm{cm}^{2}$ after $500^{\circ} \mathrm{C}$ redox cycling, respectively. This effect could be attributed to a refined microstructure in the anode functional layer after the redox cycling.

For the cell with Ni/GDC anode, no increase of the ohmic resistance was found, independent of the redox temperature (Figure $3 \mathrm{~d}$ ). Polarization resistance is slightly lower for the Ni/GDC anode showing low frequency intercept of $0.25 \Omega \mathrm{cm}^{2}$ at BOL and $0.19 \Omega \mathrm{cm}^{2}$ after the $700{ }^{\circ} \mathrm{C}$ redox cycling. Since the electrolyte is similar in both cell configurations, the small difference can only be explained by differences in the contact resistance. Post-test microstructural analysis after the cycling test revealed that the electrolyte of the cell with a Ni/YSZ anode was partly peeled off (not shown here), while the 
electrolyte in the cell with a Ni/GDC anode did not exhibit any delamination. This is likely the main reason for the strong cell degradation in the case of the $\mathrm{Ni} / \mathrm{YSZ}$ anode.
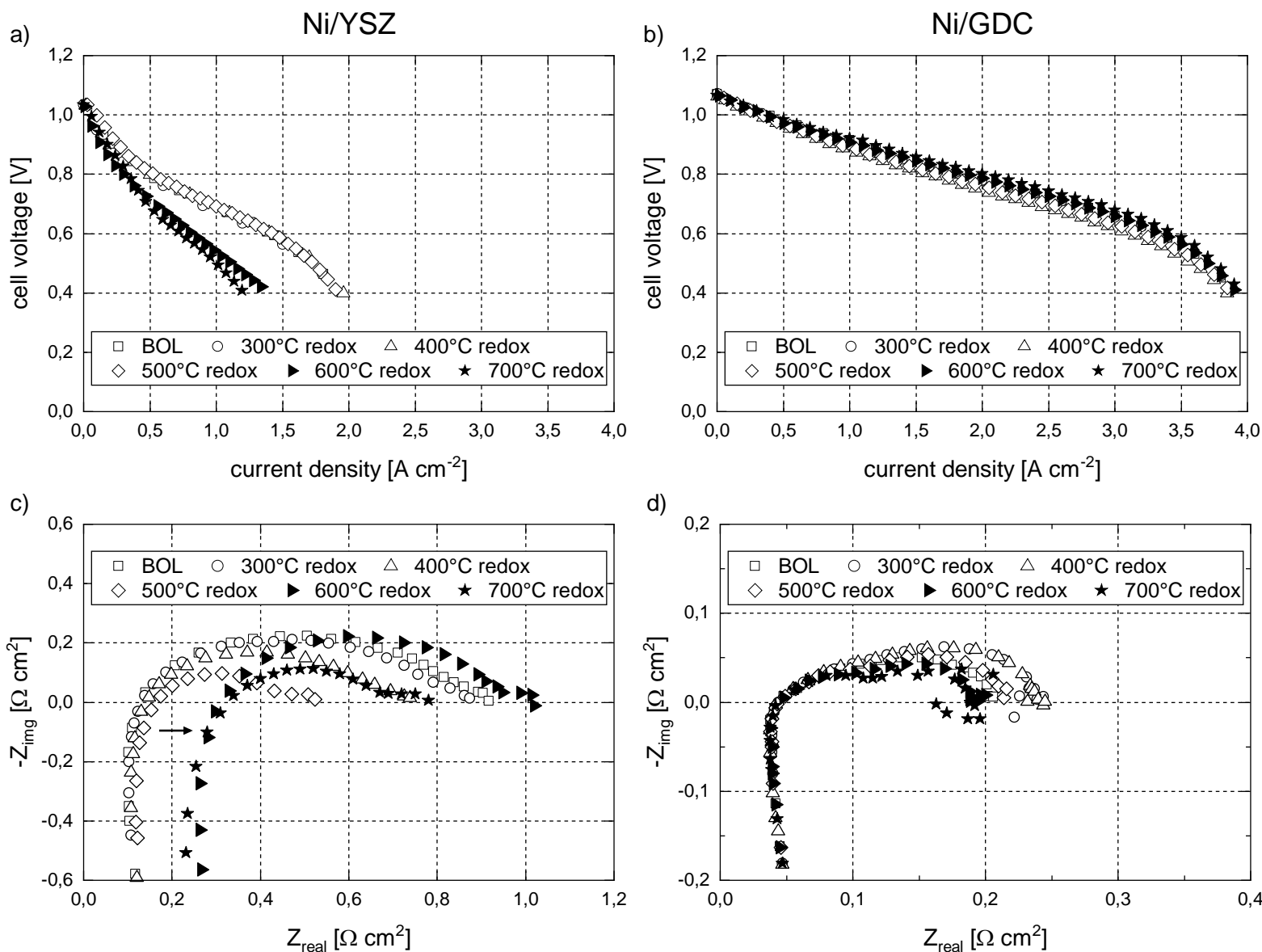

Figure 3: Performance check (I-V) and electrochemical impedance spectroscopy (EIS) at $750^{\circ} \mathrm{C}$ for cells with (a, c) a Ni/YSZ anode and (b, d) a Ni/GDC anode after redox cycles at specific temperatures.

Figure 4 shows the changes in the microstructure of the Ni/YSZ and Ni/GDC anode layers, respectively, after completing the full series of testing conditions summarized in Figure 2a. The Ni grain structure changed from large rounded grains to a finer microstructure with clearly increased internal porosity both in the $\mathrm{Ni} / \mathrm{YSZ}$ and $\mathrm{Ni} / \mathrm{GDC}$ anode layers. However, in the $\mathrm{Ni} / \mathrm{GDC}$ anode, the change of the $\mathrm{Ni}$ phase is less pronounced than in the Ni/YSZ anode, even though the same testing procedure was conducted. This might explain why the redox tolerance of cells with the Ni/GDC material is better than with the standard Ni/YSZ anodes. It was confirmed that there is no significant difference in redox stability of $\mathrm{Ni} / \mathrm{YSZ}$ and $\mathrm{Ni} / \mathrm{GDC}$ anodes at low temperatures from $300-500{ }^{\circ} \mathrm{C}$ since the redox kinetics is rather slow in this temperature regime and only marginal amount of $\mathrm{Ni}$ might be oxidized within 10 min of reoxidation. For this reason, the cell survives better at lower temperatures for both, Ni/GDC and $\mathrm{Ni} / \mathrm{YSZ}$ anodes since only weak stresses arise in the microstructure during redox cycling. 

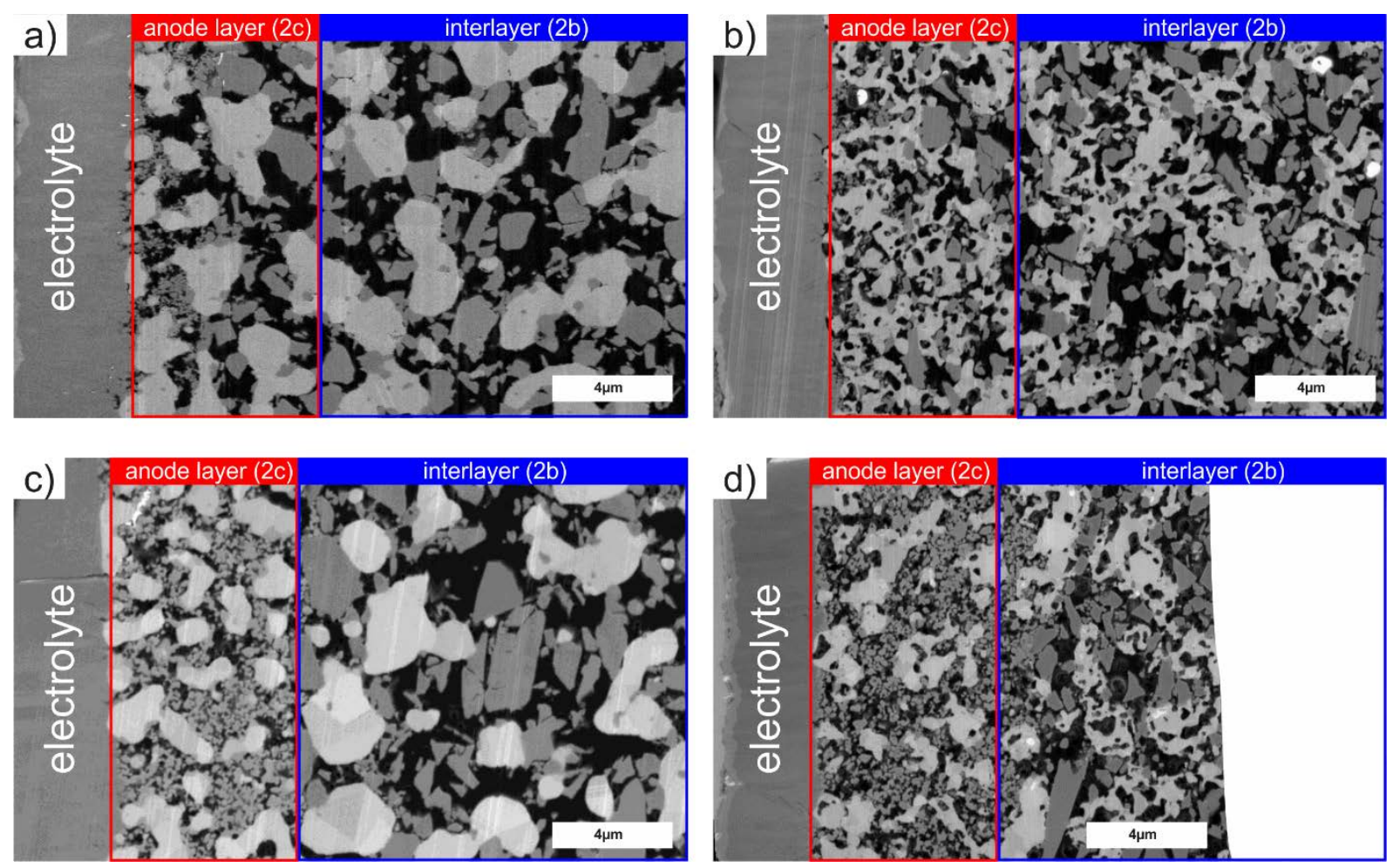

Figure 4: Comparison of the microstructures of cells with a (a, b) Ni/YSZ anode; $(c, d) \mathrm{Ni} / \mathrm{GDC}$ anode; $(a, c)$ before redox cycling; (b, d) after 35 short-term redox cycles in the temperature range of $300-700{ }^{\circ} \mathrm{C}(\mathrm{Ni}=$ bright phase, $\mathrm{YSZ}$ or GDC $=$ gray phase, pores $=$ black). . Cells were cooled down in the reduced state.

\subsection{FIB-SEM-analysis of anodes after short-term redox cycles}

By using the FIB-SEM technique, a three-dimensional digital image of the microstructure was reconstructed from the single-layer SEM images. From this 3D microstructure, information was calculated about the pore and particle size distribution (Figure 5). It thus became evident that in the $\mathrm{Ni} / \mathrm{YSZ}$ anode, the size of the $\mathrm{Ni}$ and YSZ grains as well as the size of the pores were significantly reduced after redox cycling. SEM and reconstructed 3D images indicate that the Ni particle structure was changed from a rounded to a more porous and disrupted structure, which is also indicated by the reduced grain size. The sphere packing algorithm had to be adjusted accordingly for the new microstructure. In the case of the $\mathrm{Ni} / \mathrm{GDC}$ anode, only the grain size of the $\mathrm{Ni}$ was reduced from 
$0.63 \mu \mathrm{m}$ to $0.33 \mu \mathrm{m}$ after redox cycling, while the change in size of the GDC grains and pores was statistically insignificant.
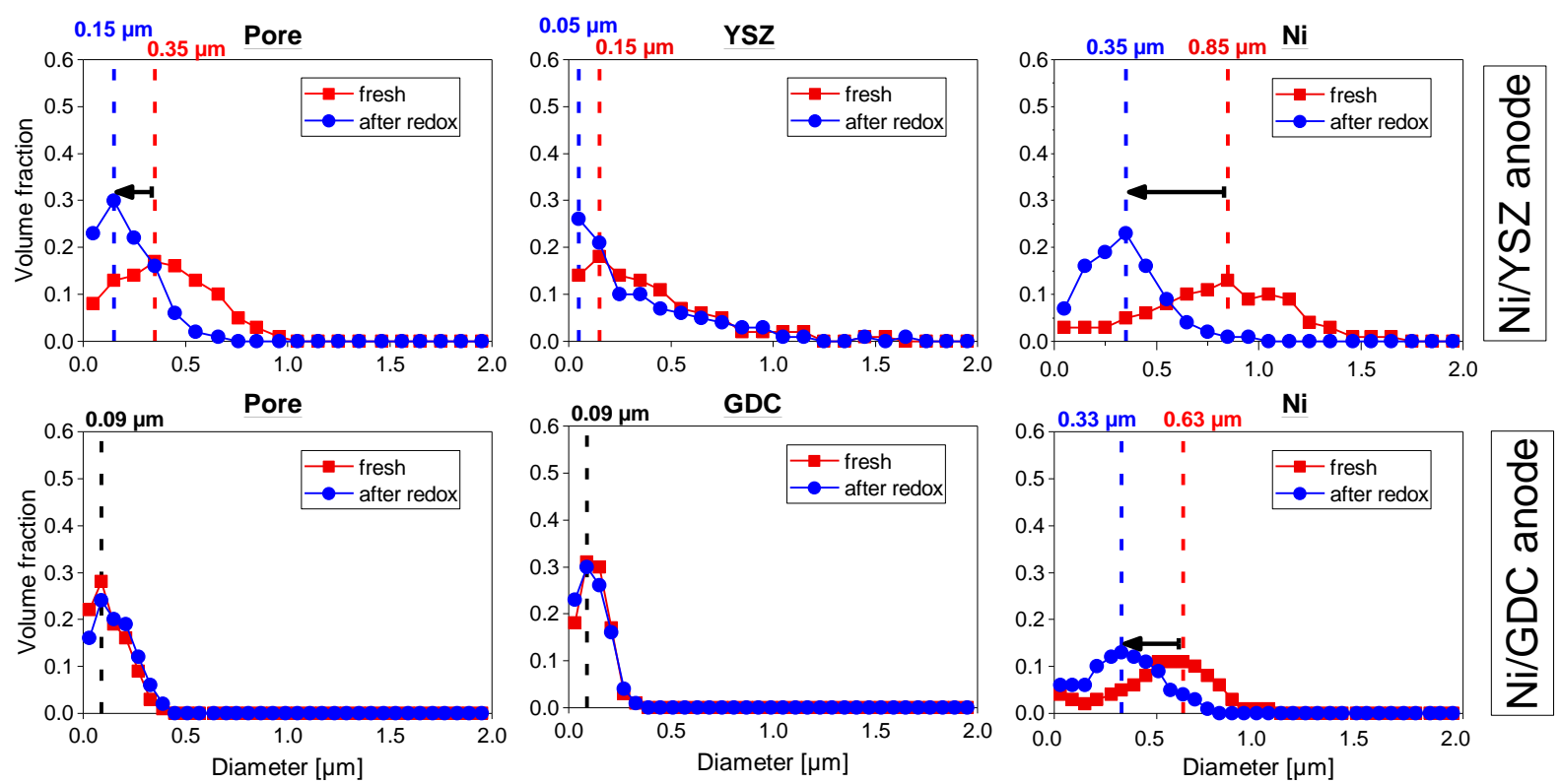

Figure 5: Diameter of pores as well as $\mathrm{Ni}$ and YSZ/GDC particles in Ni/YSZ and Ni/GDC anodes (layer 2c in Figure 1) calculated from the reconstructed FIB-SEM data.

The FIB-SEM 3D reconstruction technique also enables the calculation of the interface area between the pores and the ceramic backbone (YSZ or GDC), the YSZ (GDC) grains, and the Ni grains, as well as between the $\mathrm{Ni}$ grains and the pores. As summarized in Table 1 the interface area between the $\mathrm{Ni}$ grains and the pores, and the interface area between the YSZ grains and the Ni grains increased the most for the Ni/YSZ anode, which mainly resulted from the change of Ni morphology. In contrast, the $\mathrm{Ni} / \mathrm{GDC}$ anode microstructure remained unaffected by redox cycling for the most part. Only the interface area between the GDC grains and the pores increased slightly, which is in accordance with the slight performance increase observable in the I-V-curves in Figure $3 \mathrm{~b}$. These data do not correspond clearly with the impression from the SEM image (Figure 4), in which the Ni morphology in the $\mathrm{Ni} / G D C$ anode layer evidently changed to a more elongated shape accompanied by the formation of pores. For this reason, the interface area between the Ni grains and the pores should also increase after redox cycling. This deviation in results might be due to the indistinct border between the Ni grains and the newly formed pores when defining the gray scales from the SEM images during the 3D reconstruction process. Further optimization of the algorithm, image processing and better resolution of raw image are required especially for degraded samples.

Table 1: Calculated interface area between YSZ grains and pores (GDC grains and pores), YSZ grains and Ni grains (GDC grains and $\mathrm{Ni}$ grains), and $\mathrm{Ni}$ grains and pores in Ni/YSZ and Ni/GDC anodes (layer $2 \mathrm{c}$ in Figure 1) before and after shortterm redox cycling at $300-700^{\circ} \mathrm{C}$.

\begin{tabular}{|l|l|l|l|l|l|}
\hline \multicolumn{2}{|l|}{$\mathrm{Ni} / \mathrm{YSZ}$ anode } & After redox & $\begin{array}{l}\text { Ni/GDC anode } \\
{\left[\mu \mathrm{m}^{2} \mu \mathrm{m}^{-3}\right]}\end{array}$ & Fresh sample & After redox \\
\hline $\begin{array}{l}\text { Interface area } \\
{\left[\mu \mathrm{m}^{2} \mu \mathrm{m}^{-3}\right]}\end{array}$ & Fresh sample & area & \\
\hline $\mathrm{YSZ}-$ pore & 3.20 & 3.71 & $\mathrm{GDC}-$ pore & 7.72 & 8.55 \\
\hline $\mathrm{YSZ}-\mathrm{Ni}$ & 1.69 & 2.33 & $\mathrm{GDC}-\mathrm{Ni}$ & 3.63 & 3.77 \\
\hline $\mathrm{Ni}-$ pore & 0.35 & 2.04 & $\mathrm{Ni}-$ pore & 0.75 & 0.86 \\
\hline
\end{tabular}


The preliminary experiments with 7 redox cycles at different reoxidation temperatures showed that the $\mathrm{Ni} / \mathrm{GDC}$ anodes exhibit significantly higher redox tolerance than the $\mathrm{Ni} / \mathrm{YSZ}$ anodes, even at elevated temperatures of $600^{\circ} \mathrm{C}$ or above. For this reason, long-term testing with up to 50 redox cycles was performed on $\mathrm{Ni} / \mathrm{GDC}$ anodes at temperatures of $400{ }^{\circ} \mathrm{C}, 500{ }^{\circ} \mathrm{C}$, and $600{ }^{\circ} \mathrm{C}$, respectively.

\subsection{Long-term redox cycling at $400{ }^{\circ} \mathrm{C}, 500{ }^{\circ} \mathrm{C}$, and $600{ }^{\circ} \mathrm{C}$}

Electrochemical performance and EIS were measured during and after long-term redox cycling of cells with a Ni/GDC anode. A first test was performed at $600^{\circ} \mathrm{C}$, with the cell exhibiting good performance for up to 30 redox cycles (Figure 6a). At a higher number of cycles, the cell began to degrade strongly and current density decreased drastically. The performance drop is accompanied by an increase of the ohmic resistance, which is shown in the EIS plot in Figure 6b.

a)

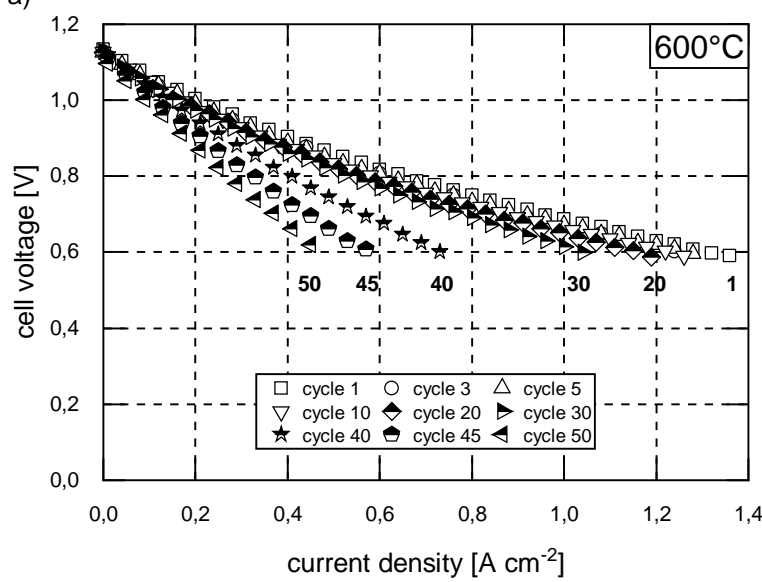

c)

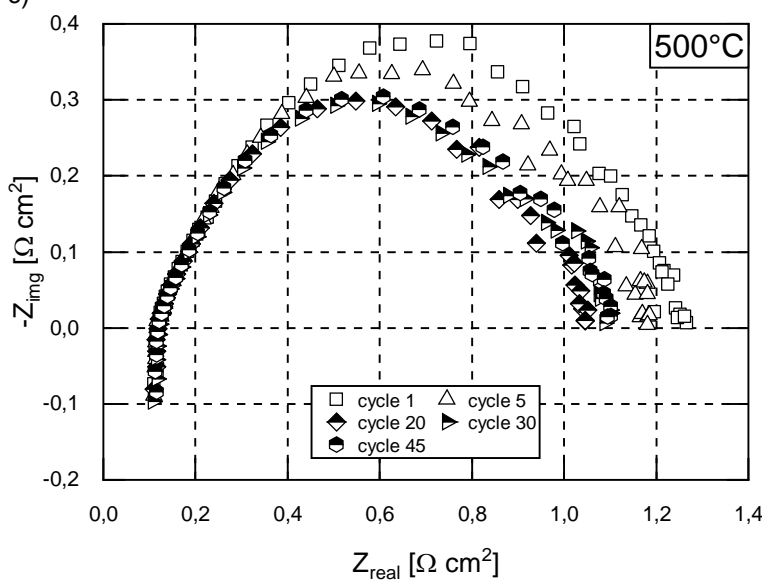

b)

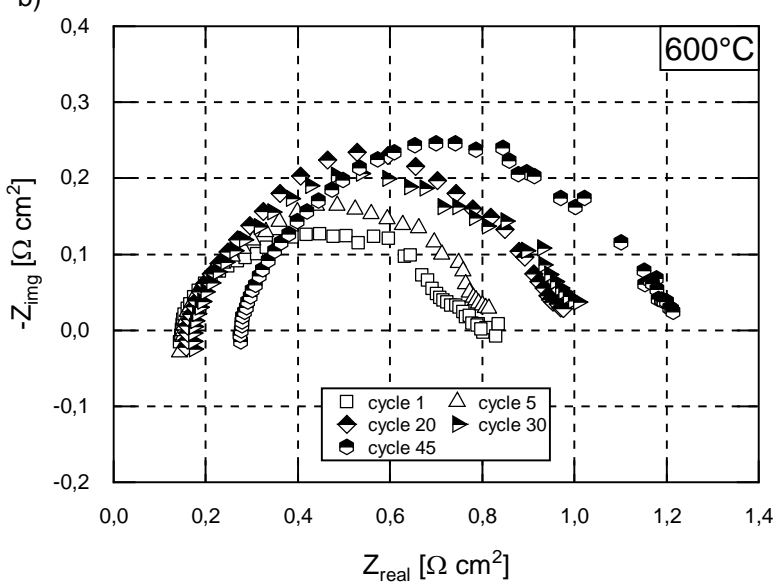

d)

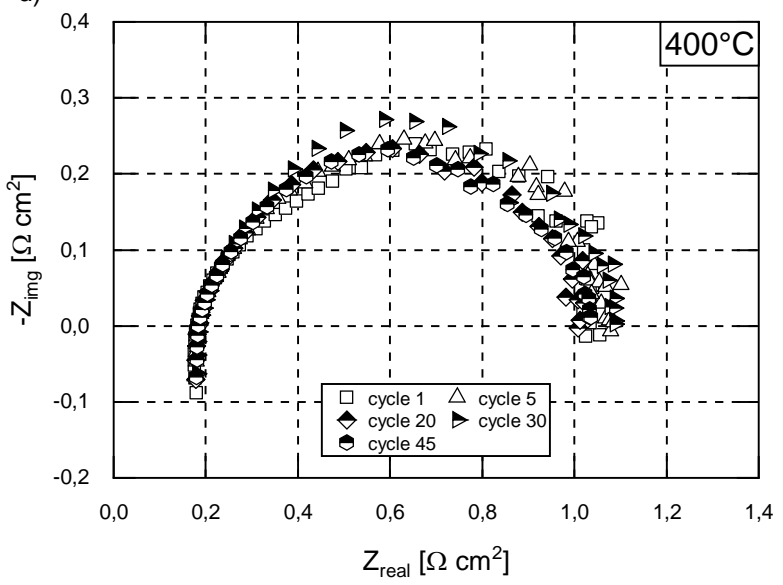

Figure 6: a) Electrochemical performance (I-V) after redox cycling at $600^{\circ} \mathrm{C}$; EIS plots of MSC test cells with a Ni/GDC anode redox cycled at b) $\left.600^{\circ} \mathrm{C}, \mathrm{C}\right) 500^{\circ} \mathrm{C}$ and d) $400^{\circ} \mathrm{C}$ depending on the number of redox cycles; data recorded at $600^{\circ} \mathrm{C}$ cell temperature each.

It is even more interesting, that the high frequency intercept also clearly changes its nature after approximately 30 redox cycles from a pure ohmic resistor (attributed to the resistance of ion conduction in the electrolyte) to a non-linear resistor. The physical background of the additional nonlinear resistive process might be associated with the electrolyte delamination due to mechanical strains and a possible evolution of a novel phase at this changed anode/electrolyte interface. A Schottky-type contact between the still percolating $\mathrm{Ni}$ in the anode and a novel interfacial phase may lead to a similar behavior but the exact reason for the high frequency axis intercept becoming non- 
linear cannot be clarified unambiguously from the data available so far. Polarization resistance increased with the number of redox cycles at $600{ }^{\circ} \mathrm{C}$, which can be attributed to microstructural changes in the electrodes. The lower current densities compared to the measurements in Figure $3 \mathrm{~b}$ are due to the lower temperature at which electrochemical characterization was performed during long-term cycling. Figure $6 \mathrm{c}$ shows an EIS plot of the cell which where redox cycled at $500^{\circ} \mathrm{C}$. It becomes obvious from this data, that there was no delamination of the electrolyte since the high frequency intercept was not affected by the redox cycling. The polarization resistance decreased slightly with the number of redox cycles at $500{ }^{\circ} \mathrm{C}$, which explains the performance improvement after 5 cycles. Electrochemical impedance remained constant while cycling at $400{ }^{\circ} \mathrm{C}$, as can be seen from Figure 6d.

Post-test analyses were performed by FIB-SEM after 5 and 50 redox cycles at $600{ }^{\circ} \mathrm{C}$, respectively, and the $3 \mathrm{D}$ microstructure was subsequently reconstructed from this data. The results indicated only minor changes in the $\mathrm{Ni} / \mathrm{GDC}$ anode microstructure after 5 redox cycles at $600^{\circ} \mathrm{C}$, whereas the microstructure had changed significantly after 50 cycles (Figure 7).

\section{Fresh sample}

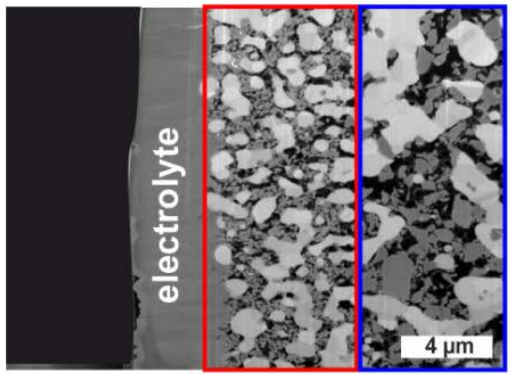

$\mathrm{Ni} / \mathrm{GDC}$ anode (2c) interlayer (2b)
After 5 redox cycles at $600{ }^{\circ} \mathrm{C}$

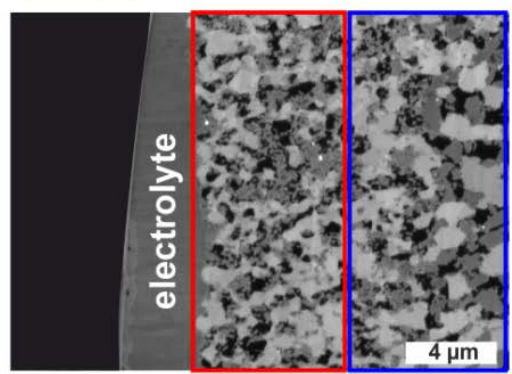

$\mathrm{Ni} / \mathrm{GDC}$ anode (2c) interlayer (2b)

\section{After 50 redox cycles at $600{ }^{\circ} \mathrm{C}$}

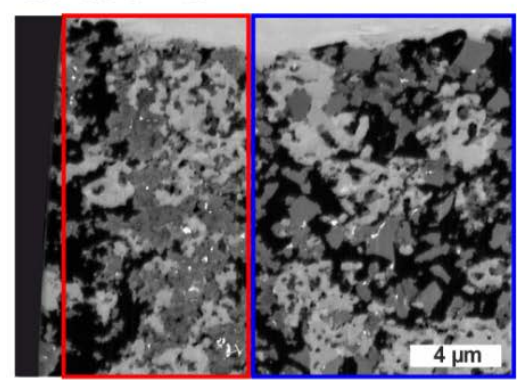

$\mathrm{Ni} / \mathrm{GDC}$ anode (2c) interlayer (2b)

Figure 7: SEM images of a Ni/GDC anode at the beginning of a fresh sample and after 5 and 50 redox cycles at $600{ }^{\circ} \mathrm{C}$. Cells are in the reduced state.

After 50 redox cycles at $600{ }^{\circ} \mathrm{C}$ the electrolyte was delaminated from the functional layer (2c in Figure 1) of the Ni/GDC anode. Moreover, the anode layer was significantly damaged and also some cracks at the interface to the $\mathrm{Ni} / \mathrm{YSZ}$ interlayer (layer $2 \mathrm{~b}$ in Figure 1) occurred. The calculated volume fraction of pore, GDC and Ni phase - determined from the 3D microstructure reconstruction of the anodes reveals no significant alteration after 5 redox cycles, as can be seen from Table 2 .

Table 2: Reconstructed volume fraction of pore, GDC, and Ni phases in the Ni/GDC anode microstructure of a fresh sample as well as after 5 redox cycles at $600{ }^{\circ} \mathrm{C}$.

\begin{tabular}{|l|l|l|}
\hline Volume fraction [\%] & Fresh sample & After 5 redox cycles at $600{ }^{\circ} \mathrm{C}$ \\
\hline Pore & 0.24 & 0.23 \\
\hline GDC & 0.37 & 0.39 \\
\hline $\mathrm{Ni}$ & 0.39 & 0.39 \\
\hline
\end{tabular}

To determine the maximum temperature of long-term redox tolerance, the redox cycling was repeated at $500{ }^{\circ} \mathrm{C}$ and $400{ }^{\circ} \mathrm{C}$ with fresh MSC samples. At both temperatures, the drop in cell performance was not as strong as was observed at $600{ }^{\circ} \mathrm{C}$ before. During redox cycling at $500^{\circ} \mathrm{C}$, cell performance is slightly improved during the initial phase and remained constant afterwards. The performance of the cell redox cycled at $400{ }^{\circ} \mathrm{C}$ remained almost constant until end of the test. No electrolyte delamination was observed for either of the cells tested at $500^{\circ} \mathrm{C}$ and $400{ }^{\circ} \mathrm{C}$. In contrast, in the cell which was redox 
cycled at $600{ }^{\circ} \mathrm{C}$, a strong increase of the ohmic resistance was observed after $35 \mathrm{cycles}$. Figure 8a shows the degradation of power density as a function of the number of redox cycles at $600{ }^{\circ} \mathrm{C}, 500{ }^{\circ} \mathrm{C}$, and $400{ }^{\circ} \mathrm{C}$, which is closely related to the evolution of the ohmic resistance plotted in Figure $8 \mathrm{~b}$. For the cell which was redox cycled at $600{ }^{\circ} \mathrm{C}$, the electrochemical performance of the cell was firstly deteriorated by slight increase of ohmic resistance, and then a strong performance drop happened due to a steep increase of ohmic resistance after 35 cycles. Contrary to that, the performance of the cells which were cycled at lower temperatures of $500{ }^{\circ} \mathrm{C}$ and $400{ }^{\circ} \mathrm{C}$ did not decrease in such a way. Power density rather increased slightly after 5 cycles and the ohmic resistance did not change at all over the 50 redox cycles.
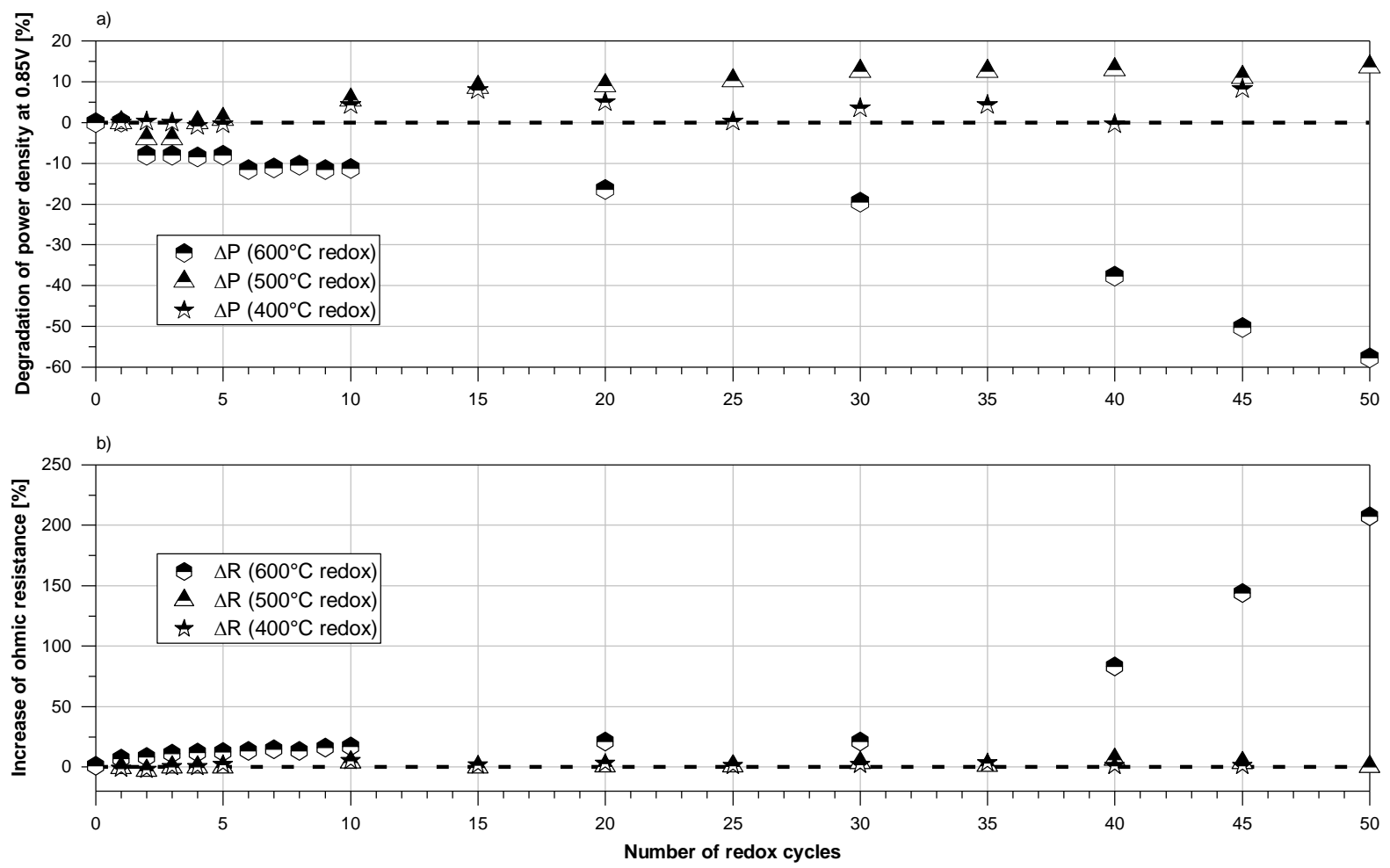

Figure 8: a) Degradation of the power density of an MSC test cell with a Ni/GDC anode as a result of b) ohmic resistance increasing with the number of redox cycles at $600^{\circ} \mathrm{C}, 500^{\circ} \mathrm{C}$, and $400^{\circ} \mathrm{C}$; data recorded at $600^{\circ} \mathrm{C}$ cell temperature each.

Since we omitted steady-state operation with a constant current after redox cycling in this study, the coarsening of $\mathrm{Ni}$ accompanied with an increase of the polarization resistance - as was reported, for example, by Iwanschitz et al. [15] - virtually did not take place. Nevertheless, Ni/GDC anodes underwent significant microstructural changes if the number of redox cycles was increased to 50 and if the period of time for oxidation and reduction was increased to $120 \mathrm{~min}$. Redox cycling at $600{ }^{\circ} \mathrm{C}$ under these conditions led to a remarkable increase of the ohmic resistance after 20-30 cycles and a significant loss of power density after 35 cycles. This behavior indicated a failure or delamination of the electrolyte, which was confirmed by post-test analysis after completing the 50 cycles. Furthermore, the FIB-SEM investigation identified the accelerated coarsening of $\mathrm{Ni}$ in contact with the GDC as one possible reason for electrolyte delamination. Several authors $[35,45]$ have reported stronger $\mathrm{Ni}$ coarsening in the presence of the GDC due to strong interfacial interaction. This must also be considered during the processing of Ni/GDC anodes [13].

\section{Conclusions}

To the best of our knowledge, this is the first time that a comprehensive study on the redox tolerance of metal-supported fuel cells with $\mathrm{Ni} / \mathrm{YSZ}$ and $\mathrm{Ni} / \mathrm{GDC}$ anodes has been conducted. Other studies 
investigated YSZ or GDC containing anodes either on ASCs $[19,21,23]$ or on electrolyte supported model electrodes $[15,29,30,35]$ only. The cell concept, which was used for this study and was mainly developed for mobile applications such as a range extenders in battery electric vehicles, is ideal for such investigations since it enables the implementation of $\mathrm{Ni} / \mathrm{YSZ}$ or Ni/GDC anodes by accordingly adapting the processing technology. Both types of cell designs were investigated according to their redox tolerance in a comparative way on full metal supported fuel cells.

In the literature, Ni/GDC anodes are reported as being more suitable for this type of application because they promise increased electrochemical activity due to the mixed ionic and electronic conducting GDC phase [13] as well as improved redox tolerance [15, 35]. Mobile applications usually require SOFC operation temperatures below $700^{\circ} \mathrm{C}$, which is beneficial for redox tolerance detrimental processes such as the oxidation of $\mathrm{Ni}$ become significantly slower [25].

The present study provided an in-depth investigation into the tolerance of the Plansee MSC concept against harsh redox cycles. The cell concept enables the implementation of Ni/YSZ or Ni/GDC anodes by adapting the processing conditions accordingly. However, the application of $\mathrm{Ni} / G D C$ anodes was found to be advantageous for two reasons. Firstly, the electrochemical performance of the MSC was significantly improved by implementing the $\mathrm{Ni} / \mathrm{GDC}$ anode instead of the Ni/YSZ anode. At $750{ }^{\circ} \mathrm{C}$ and $0.7 \mathrm{~V}$, the power density was increased by almost a factor of three from $0.658 \mathrm{~W} \mathrm{~cm}^{-2}$ (MSC with Ni/YSZ anode) to $1.89 \mathrm{~W} \mathrm{~cm}^{-2}$ (MSC with Ni/GDC anode). Secondly, the redox tolerance of MSCs with a Ni/GDC anode was found to be significantly higher. In the case of short-term redox cycling at temperatures in the range of $300^{\circ} \mathrm{C}$ to $700^{\circ} \mathrm{C}$, the electrochemical performance of the MSCs with a Ni/GDC anode even improved with an increasing number of redox cycles. Contrary to that, MSCs with a $\mathrm{Ni} / \mathrm{YSZ}$ anode totally failed relatively early under the same redox conditions, mainly due to a delamination of the electrolyte. However, it is not completely clear if all the nickel was oxidized within the 10 minutes of reoxidation, especially at lower temperatures where the redox kinetics is much slower and the cells survive better, even in the $\mathrm{Ni} / \mathrm{YSZ}$ configuration. Moreover, we could not separate the effect of material and microstructure so far, since not only the anode material was changed ( $\mathrm{Ni} / \mathrm{YSZ}$ to $\mathrm{Ni} / \mathrm{GDC}$ ) but also the anode microstructure from coarse in the Ni/YSZ anode to finer structured Ni/GDC in this work. For finer $\mathrm{Ni}$ we suppose that the duration until the particles are oxidized becomes shorter because of the higher surface area. However, tolerance against oxidation of the finer structured $\mathrm{Ni} / \mathrm{GDC}$ anode improved compared to the $\mathrm{Ni} / \mathrm{YSZ}$ one and therefore we have to consider the effect of GDC and its material properties as i.) High storage capacity due to the potentially easy change of valence charge $\left(\mathrm{Ce}^{3+} \leftrightarrow \mathrm{Ce}^{4+}\right)$ and ii.) Oxygen vacancies in the GDC lattice.

The effect of improved performance of the Ni/GDC anode could be attributed to the refinement of the $\mathrm{Ni}$ phase caused by the redox cycling and the increase of the interface area between GDC grains and pores. Similar results were reported by Matsui et al. [35], where ceria migrated on the Ni surface after redox treatment and formed additional interface area between Ni and GDC and between GDC and the pores as well. Progressive covering of the Ni surface by GDC might be advantageous for redox tolerance for two reasons: i.) Free nickel surface, which can get in direct contact with the oxidizing atmosphere, becomes more and more decreased. Since GDC is electrochemically active as well, this must not necessarily decrease the electrochemical performance; ii.) GDC in the reduced state might act as a getter for oxygen and for this reason could help to prevent the nickel from oxidation. We consider that the material properties of GDC contribute to the suppression of nickel oxidation and improvement of the redox stability. However, to support this consideration the redox stability of a fine structured $\mathrm{Ni} / \mathrm{YSZ}$ anode with extended duration of oxidation, as well as determining the oxygen storage 
capacities of each YSZ and GDC in the anode structure (to be evaluated by TPR: Thermal Programmed Reduction) are required for future investigations.

MSCs with a Ni/GDC anode showed a stable redox tolerance for redox cycles at $400{ }^{\circ} \mathrm{C}$ and $500{ }^{\circ} \mathrm{C}$ with 120 min of reoxidation for 50 cycles, respectively. However, the redox cycling test at $600{ }^{\circ} \mathrm{C}$ caused severe cell degradation due to electrolyte delamination in this specific cell specification. For this reason, the temperature of the fuel cell should be reduced below $600{ }^{\circ} \mathrm{C}$ when reoxidation of the anode must be feared during operation. Since $500{ }^{\circ} \mathrm{C}$ is rather close to the desired operation temperature of MSCs for mobile applications, these results are very promising for this type of application since they indicate a feasible way towards a practice-oriented rapid startup and shut-down of such mobile power systems. GDC is prone to compensate mechanical stresses in the cell by chemical expansion while the volume of $\mathrm{NiO}$ decreases when being reduced. Another strategy would be to develop nickel free MIEC anodes or anode materials with Ni-exsolution effect, which can be reincorporated to the host material in oxidizing atmosphere. In order to improve cell performance at lower temperatures $\left(400-500^{\circ} \mathrm{C}\right)$, highly conductive and/or thinner electrolytes and more active cathode materials with high surface exchange coefficient and better ionic/electronic conductivity are required.

\section{Acknowledgements}

The Christian Doppler Laboratories are funded in equal measure by the public authorities and the companies directly involved in the laboratories. We are very grateful for the funding provided by the Austrian Federal Ministry for Digital and Economic Affairs and the National Foundation for Research, Technology and Development.

\section{References}

[1] M.C. Tucker, Journal of Power Sources, 195 (2010) 4570-4582.

[2] V.V. Krishnan, Wiley Interdisciplinary Reviews: Energy and Environment, (2017).

[3] M.C. Tucker, B. Carreon, J. Charyasatit, K. Langston, C. Taylor, J. Manjarrez, N. Burton, M. LaBarbera, C.P. Jacobson, ECS Transactions, 57 (2013) 503-509.

[4] E. Dogdibegovic, R. Wang, G.Y. Lau, M.C. Tucker, Journal of Power Sources, 410-411 (2019) 91-98.

[5] P. Bance, N.P. Brandon, B. Girvan, P. Holbeche, S. O'Dea, B.C.H. Steele, Journal of Power Sources, 131 (2004) 86-90.

[6] R.T. Leah, A. Bone, M. Lankin, A. Selcuk, M. Rahman, A. Clare, L. Rees, S. Phillip, S. Mukerjee, M. Selby, ECS Transactions, 68 (2015) 95-107.

[7] P. Blennow, J. Hjelm, T. Klemens $\varnothing$, S. Ramousse, A. Kromp, A. Leonide, A. Weber, Journal of Power Sources, 196 (2011) 7117-7125.

[8] B.J. McKenna, N. Christiansen, R. Schauperl, P. Prenninger, J. Nielsen, P. Blennow, T. Klemens $\varnothing$, S. Ramousse, A. Kromp, A. Weber, Fuel Cells, 13 (2013) 592-597.

[9] J. Nielsen, Å.H. Persson, T.T. Muhl, K. Brodersen, Journal of The Electrochemical Society, 165 (2018) F90-F96.

[10] A. Ansar, P. Szabo, J. Arnold, Z. Ilhan, D. Soysal, R. Costa, A. Zagst, M. Gindrat, T. Franco, ECS Transactions, 35 (2011) 147-155.

[11] T. Franco, M. Haydn, A. Weber, W. Schafbauer, L. Blum, U. Packbier, D. Roehrens, N.H. Menzler, J. Rechberger, A. Venskutonis, L.S. Sigl, H.P. Buchkremer, ECS Transactions, 57 (2013) 471-480.

[12] M. Haydn, K. Ortner, T. Franco, S. Uhlenbruck, N.H. Menzler, D. Stöver, G. Bräuer, A. Venskutonis, L.S. Sigl, H.-P. Buchkremer, R. Vaßen, Journal of Power Sources, 256 (2014) 52-60. 
[13] V.A. Rojek-Wöckner, A.K. Opitz, M. Brandner, J. Mathé, M. Bram, Journal of Power Sources, 328 (2016) 65-74.

[14] O. Kesler, M. Cuglietta, J. Harris, J. Kuhn, M. Marr, C. Metcalfe, ECS Transactions, 57 (2013) 491501.

[15] B. Iwanschitz, J. Sfeir, A. Mai, M. Schütze, Journal of The Electrochemical Society, 157 (2010) B269B278.

[16] D. Fouquet, A.C. Muller, A. Weber, E. Ivers-Tiffee, lonics, 9 (2003) 103-108.

[17] D. Waldbillig, A. Wood, D.G. Ivey, Solid State Ionics, 176 (2005) 847-859.

[18] M. Pihlatie, A. Kaiser, P.H. Larsen, M. Mogensen, Journal of The Electrochemical Society, 156 (2009) B322-B329.

[19] M. Ettler, G. Blaß, N.H. Menzler, Fuel Cells, 7 (2007) 349-355.

[20] J. Malzbender, E. Wessel, R.W. Steinbrech, Solid State lonics, 176 (2005) 2201-2203.

[21] M. Ettler, H. Timmermann, J. Malzbender, A. Weber, N.H. Menzler, Journal of Power Sources, 195 (2010) 5452-5467.

[22] D. Sarantaridis, R.A. Rudkin, A. Atkinson, ECS Transactions, 7 (2007) 1491-1499.

[23] D. Sarantaridis, A. Atkinson, Fuel Cells, 7 (2007) 246-258.

[24] Q. Jeangros, A. Faes, J.B. Wagner, T.W. Hansen, U. Aschauer, J. Van herle, A. Hessler-Wyser, R.E. Dunin-Borkowski, Acta Materialia, 58 (2010) 4578-4589.

[25] D. Waldbillig, A. Wood, D.G. Ivey, Journal of Power Sources, 145 (2005) 206-215.

[26] M. Pihlatie, A. Kaiser, M. Mogensen, Solid State Ionics, 180 (2009) 1100-1112.

[27] M. Pihlatie, A. Kaiser, M. Mogensen, Journal of the European Ceramic Society, 29 (2009) 16571664.

[28] A. Faes, A. Nakajo, A. Hessler-Wyser, D. Dubois, A. Brisse, S. Modena, J. Van herle, Journal of Power Sources, 193 (2009) 55-64.

[29] B. Song, E. Ruiz-Trejo, A. Bertei, N.P. Brandon, Journal of Power Sources, 374 (2018) 61-68.

[30] T. Shimura, Z. Jiao, S. Hara, N. Shikazono, Journal of Power Sources, 267 (2014) 58-68.

[31] J.T. Richardson, R. Scates, M.V. Twigg, Applied Catalysis A: General, 246 (2003) 137-150.

[32] J. Laurencin, G. Delette, B. Morel, F. Lefebvre-Joud, M. Dupeux, Journal of Power Sources, 192 (2009) 344-352.

[33] O.M. Pecho, A. Mai, B. Munch, T. Hocker, R.J. Flatt, L. Holzer, Materials, 8 (2015) 7129-7144.

[34] K. Park, S. Yu, J. Bae, H. Kim, Y. Ko, International Journal of Hydrogen Energy, 35 (2010) 8670-8677.

[35] T. Matsui, K. Eguchi, K. Shirai, T. Ozeki, T. Okanishi, H. Muroyama, K. Eguchi, Journal of The Electrochemical Society, 164 (2017) F1368-F1374.

[36] O. Korjus, J. Aruväli, I. Kivi, M. Kodu, E. Lust, G. Nurk, Journal of The Electrochemical Society, 165 (2018) F1043-F1050.

[37] M.C. Tucker, G.Y. Lau, C.P. Jacobson, L.C. DeJonghe, S.J. Visco, Journal of Power Sources, 175 (2008) 447-451.

[38] M.C. Tucker, Journal of Power Sources, 369 (2017) 6-12.

[39] O.A. Marina, C. Bagger, S. Primdahl, M. Mogensen, Solid State lonics, 123 (1999) 199-208.

[40] C. Bischof, A. Malleier, L. Martetschläger, A. Gladbach, S. Hummel, W. Schafbauer, M. Bram, in: Proceedings of the $13^{\text {th }}$ European SOFC \& SOE Forum, Lucerne, 03 - 06 July, 2018, pp. A15-19 - A15-28.

[41] M. Gong, X. Liu, J. Trembly, C. Johnson, Journal of Power Sources, 168 (2007) 289-298.

[42] D. Marrocchelli, S.R. Bishop, H.L. Tuller, B. Yildiz, Advanced Functional Materials, 22 (2012) 19581965.

[43] D.W. Ni, J.A. Glasscock, A. Pons, W. Zhang, A. Prasad, S. Sanna, N. Pryds, V. Esposito, Journal of The Electrochemical Society, 161 (2014) F3072-F3078. 
[44] S.P.S. Badwal, D. Fini, F.T. Ciacchi, C. Munnings, J.A. Kimpton, J. Drennan, Journal of Materials Chemistry A, 1 (2013) 10768-10782.

[45] Z. Jiao, N. Shikazono, ECS Transactions, 78 (2017) 1169-1177. 